Vol. V No. 2, Maret 2021, hlm. 137 - 144

DOI: https://doi.org/10.36294/jmp.vxix.xxx

Available online www.jurnal.una.ac.id/indeks/jmp

\title{
ANALISIS KESULITAN BELAJAR VIA WHATSAPP SISWA KELAS X PADA MASA PANDEMI COVID-19
}

\author{
Ulty Chika Putri ${ }^{1}$, Eva Margaretha Saragih ${ }^{2}$, Dewi Astuti ${ }^{3}$ \\ ${ }_{1,2,3}$ Pendidikan Matematika, Universitas Asahan \\ email: agethaevasaragih@gmail.com
}

\begin{abstract}
This study aims to analyze how learning difficulties via WhatsApp are carried out by students in solving math problems, especially on the material for the three-variable linear equation system in class X SMAN 2 Tanjungbalai T.A 2019-2020 during the COVID-19 pandemic. This research uses a qualitative approach. This type of research is a qualitative research. The sample of this study were students of class X-MIA1 SMAN 2 Tanjungbalai T.A 2019-2020, who had studied the material of the three-variable linear equation system. Students who were sampled were 27 people. The technique of analyzing student assessments is done by calculating the percentage of students who have difficulty in each stage of the 3 tests given. Based on the analysis of the data obtained from the research results, it turns out that the X-MIAl class students of SMA N 2 Tanjung balai still have difficulty learning via WhatsApp in solving the three-variable linear equation system material during the COVID-19 pandemic with the results obtained a presentation of the type of difficulty, namely difficulty facts amounted to 53.0\%, concept difficulties were $37.0 \%$, operating difficulties were $65.3 \%$, and principle difficulties were $34.5 \%$. From the discussion of the results of research conducted in class X SMAN 2 Tanjungbalai, it can be concluded that there are still many students who have difficulty learning via WhatsApp in the process of solving three-variable linear equation system material problems during the COVID-19 pandemic.
\end{abstract}

Keywords: Learning Difficulties, Via Whatsapp, Three Variable Linear Equation Systems

\begin{abstract}
Abstrak
Penelitian ini bertujuan untuk menganalisis kesulitan belajar via whatsapp yang dilakukan siswa dalam menyelesaikan soal matematika khususnya pada materi sistem persamaan linier tiga variabel di kelas X SMAN 2 Tanjungbalai T.A 2019-2020 pada masa pandemi COVID-19. Penelitian ini menggunakan pendekatan kualitatif. Jenis penelitian ini adalah penelitian kualitatif . Adapun sampel penelitian ini adalah siswa kelas X-MIA1 SMAN 2 Tanjungbalai T.A 2019-2020, yang telah mempelajari materi sistem persamaan linier tiga variabel Siswa yang dijadikan sampel sebanyak 27 orang. Teknik menganalisis penilaian siswa dilakukan dengan menghitung persentase siswa yang mengalami kesulitan setiap tahap dari 3 tes yang diberikan. Berdasarkan analisa data yang diperoleh dari hasil penelitian, ternyata siswa kelas X-MIA1 SMA N 2 Tanjung balai masih terdapat kesulitan belajar via whatsapp dalam menyelesaikan soal materi sistem persamaan linier tiga variabel pada masa pandemi COVID-19 dengan hasil yang diperoleh presentasi jenis kesulitan yaitu kesulitan fakta sebesar 53,0\%, kesulitan konsep sebesar 37,0\%, kesulitan operasi sebesar 65,3\%, dan kesulitan prinsip sebesar 34,5\%. Dari pembahasan hasil penelitian yang dilakukan di kelas X SMAN 2 Tanjungbalai dapat disimpulkan bahwa masih banyak siswa yang melakukan kesulitan belajar via whatsapp dalam proses penyelesaian soal materi sistem persamaan linier tiga variabel pada masa pandemi COVID-19.
\end{abstract}

Kata Kunci: Kesulitan Belajar, Via WhatsApp, Sistem Persamaan Linier Tiga Variabel 
Vol. V No. 2, Maret 2021, hlm. 137 - 144

DOI: https://doi.org/10.36294/jmp.vxix.xxx

Available online www.jurnal.una.ac.id/indeks/jmp

\section{PENDAHULUAN}

Dalam dunia pendidikan mata pelajaran matematika sangat berperan penting untuk dikuasai siswa karena matematika merupakan salah satu cabang ilmu yang mempunyai banyak manfaat bagi perkembangan ilmu pengetahuan dan teknologi. Perkembangan yang pesat dibidang teknologi informasi dan komunikasi, dilandasi oleh perkembangan matematika oleh sebab itu matematika mempunyai peranan yang sangat penting dalam berbagai disiplin ilmu sehingga dapat memajukan daya pikir manusia.

Oleh karena itu, untuk menguasai dan mengembangkan ilmu pengetahuan dan teknologi informasi serta mampu bertahan hidup pada keadaan yang selalu berubah dan kompetitif dimasa depan diperlukan penguasaan matematika yang kuat sejak dini.

Ditengah wabah pandemi covid19 yang melanda dunia khususnya Indonesia saat ini sedang berada dalam kesedihan mendalam akibat mewabahnya Coronavirus Disease (Covid-19) bermula timbul di Wuhan, Cina dan telah diumumkan sebagai pandemic oleh organisasi kesehatan dunia.

Menurut kementerian kesehatan (dalam Pratiwi, E. W,. 2020:2) mengemukakan bahwa coronavirus merupkan keluarga virus yang menyebabkan penyakit mulai dari gejala ringan hingga berat, jenis coronavirus diketahui menyebabkan penyakit yang dapat menimbulkan gejala berat seperti Middle East Respiratory Syndrome (MERS) DAN Severe Acute Respiratory Syndrome (SARS).
World Health Organization memberi nama virus baru tersebut Servere acute respiratory syndrome coronavirus-2(SARS-COV-2) dan nama penyakitnya sebagai Coronavirus Disease 2019 (COVID19).

Menurut Nuraini (dalam Pratiwi, E. W, 2020:2) Diduga covid-19 pertama kali muncul di Wuhan, Provinsi Hubei, Tiongkok virus ini diduga muncul karena adanya sebuah pasar makanan diwuhan yang menjual berbagai jenis hewan hidup maupun sudah mati Virus ini telah tersebar disleuruh dunia termasuk Indonesia sejak awal bulan maret 2020. Pemerintah Indonesia langsung menindak lanjuti kassus tersebut. Salah satu tindakan pemerintah adalah melakukan social distancing selama 14 hari untuk meminimalisir penyebaran virus tersebut. Menurut Center for Disease $(C D C)$ social distancing yaitu menjauhi perkumpulan, menghindari pertemuan massal, dan menjaga jarak antar manusia. Pembatasan sosial / menjaga jarak yang dilakukan untuk mencegah penularan covid-19 agar tidak meneyebar luas di Negara Indonesia (Mapilindo, M., \& Anim, A. 2020).

Social Distancing sangat berpengaruh untuk menghambat penyebaran covid-19. Dampak dari adanya covid-19 tersebut, menyebabkan perekonomian di Indonesia menjadi merosot, menjatuhkan nilai tukar rupiah, harga barang naik terutama alat-alat kesehatan (Anim, A. 2020). Hal ini juga berdampak pada sistem pendidikan di Indonesia. Hasil keputusan dari menteri pendidikan 
Vol. V No. 2, Maret 2021, hlm. 137 - 144

DOI: https://doi.org/10.36294/jmp.vxix.xxx

Available online www.jurnal.una.ac.id/indeks/jmp

bahwa seluruh kegiatan pembelajaran baik disekolah maupun perguruan tinggi dilaksanakan dirumah masing-masing melalaui aplikasi yang tersedia. Menurut Kemdikbud RI (dalam Pratiwi, E. W,. 2020:2) menyatakn bahwa menteri pendidikan mengeluarkan surat edaran nomor 3 tahun 2020 tentang penecegahan corona virus disease (covid-19) pada satuan pendidikan yang menyatakan bahwa meliburkan sekolah dan perguruan tinggi. Hal ini dilakukan untuk memutus rantai penyebaran covid-19, sebagai gantinya kegiatan pembelajaran dilakukan secara online untuk semua jenjang pendidikan.

Oleh karena itu guna mendukung pemerintah, proses pembelajaran disekolah maupun kampus secara tatap muka di kelas di STOP, di ganti oleh pembelajaran jarak jauh (Anim, A., \& Nisa, K. 2020).
Sistem jarak jauh menjadi salah satu solusi untuk mengatasi kesulitan dalam pembelajaran secara langsung dengan adanya aturan social distancing mengingat permasalahan waktu, lokasi, jarak dan biaya yang menjadi kendala besar saat ini. Pendidikan jarak jauh atau dapat juga disebut sebagai pembelajaran jarak jauh, saat ini hampir semua para pelaku pendidikan menjadikannya salah satu solusi pembelajaran dalam mengahadapi wabah pandemi Covid19. Pada saaat ini pembelajaran matematika di sekolah menengah atas belum dapat dikatakan berhasil sepenuhnya, hal ini dapat di lihat dari beberapa siswa yang belum mampu memahami serta merasa kesulitan ketika belajar mata pelajaran matematika, hal ini dapat di lihat dari hasil jawaban siswa dalam meyelesaikan soal tersebut

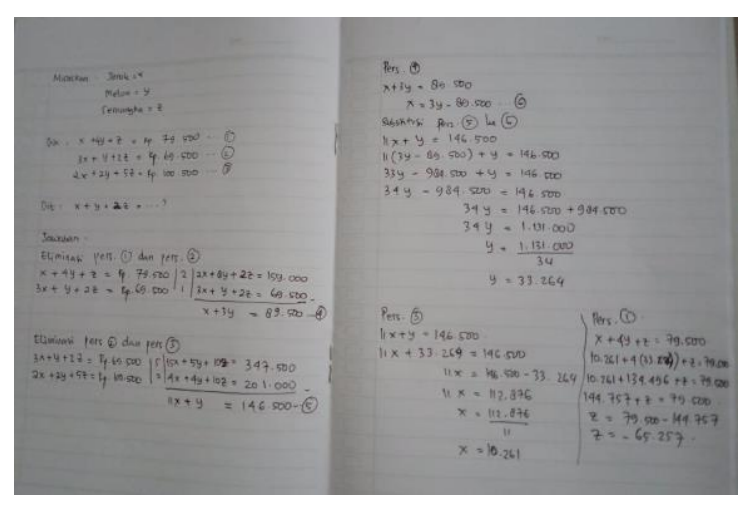

Gambar 1. Salah satu hasil jawaban siswa

Pada gambar 1.1 diatas, terlihat bahwa soal diatas merupakan soal sederhana yang sering di temui dalam kehidupan sehari-hari, namun soal tersebut akan sulit untuk diselesaikan oleh siswa ketika siswa tidak mampu memahami soal yang diberikan guru.

Adapun faktor kesulitan belajar siswa dapat kita lihat pasca wabah pandemi covid-19 yang mengharuskan kegiatan pembelajaran online melalui via 
Vol. V No. 2, Maret 2021, hlm. 137 - 144

DOI: https://doi.org/10.36294/jmp.vxix.xxx

Available online www.jurnal.una.ac.id/indeks/jmp

whatsapp group ini dilakukan untuk mengganti kegiatan pembelajaran secara langsung yakni ketika pada saat guru memberikan soal maupun materi masih banyak siswa yang pasif sehingga diskusi menjadi kurang maksimal, sering terjadi gangguan jaringan pada penggunaan whatsapp, dan bagi siswa yang kurang aktif pada saat diskusi dimedia whatsapp group juga mengalami kesulitan karena banyak ketertinggalan materi pembelajaran terutama bagi siswa yang cenderung memiliki pemahaman rendah sehingga hal-hal tersebut dapat mempengaruhi kesulitan belajar siswa.

Media sosial whatsapp (WA) merupakan salah satu media komunikasi yang saat ini banyak digandrungi oleh seluruh lapisan masyarakat. Pengguna media sosial WA ini sudah menjadi salah satu media sosial yang mencakup keseluruhan kepentingan masyarakat dalam berkomunikasi memenuhi keperluan masing-masing. Menurut Jubile Enterprise (dalam Kusuma, J. W., dkk 2012:100)mendefenisikan whatsapp sebagai aplikasi chatting dimana anda bisa mengirim pesan teks, gambar, suara, lokasi dan bahkan video keorang lain dengan menggunakan smartphone apapun.

Whatsapp dalam penggunaannya sebagai media chat digital yang mencakup pesan, teks, gambar, video dan dapat untuk menelpon menjadi satu kesatuan yang lengkap untuk membantu masyarakat dalam menjalin komunikasi diseluruh belahan dunia. Menurut Suryadi (dalam Kusuma, J. W., dkk 2018:100) menambahkan jika dilihat dari fungsinya whatsapp hampir sama dengan aplikasi SMS yang bisa dipergunakan diponsel lama. Namun, whatsapp ini tidak menggunakan pulsa seperti biaya sms pada umumnya, pada whatsapp ini menggunakan jaringan internet sesuai dengan perkembangan teknologi yang saat ini terhubung dengan jaringan dan terindetifikasi dengan nomoh handphone (hp).

Aplikasi whatsapp ini juga dilengkapi dengan berbagai pilihan yang mendukung seperti adanya New group, new broadcast, whatsapp web, starred messages and settigs. Fitur lengkap yang tersedia diaplikasi whatsapp membuat penggunanya semakin meningkat pesat. Berbagai pilihan yang tersedia di whatsapp tersebut salah satunya new group yang belakangan ini banyak digunakan pada pelajar, mahasiswa, guru dan dosen sebagai media komunikasi yang terhalang oleh jarak yang disebut whatsapp group. Whatsapp group tersebut saat ini dijadikan wadah diskusi untuk memecahkan berbagai massalah, pertanyaan dan sesuatu yang penting yang harus disampaikan terhadap orang-orang yang tergabung didalamnya. Diskusi melalaui whatsapp group ini sangat membantu penggunanya untuk berkomunikasi dalam pembelajaran jarak jauh.

Dalam pembelajaran matematika, jika anak mengalami kesulitan belajar dianggap sebagai suatu hal yang biasa dan sudah realita umumnya seperti ini Hal ini disebabkan karena matematika merupakan pelajaran yang menjadi momok menakutkan bagi anak-anak. 
Vol. V No. 2, Maret 2021, hlm. 137 - 144

DOI: https://doi.org/10.36294/jmp.vxix.xxx

Available online www.jurnal.una.ac.id/indeks/jmp

Ada banyak faktor yang mempengaruhi kesulitan belajar matematika anak, yang secara umum berupa faktor dari dalam diri anak sendiri dan faktor dari luar diri anak. Adanya kesulitan siswa dalam menyelesaikan masalah matematika perlu mendapat perhatian. Kesulitan yang dilakukan siswa dalam memecahkan masalah matematika perlu diidentifikasi apa saja yang mempengaruhinya kemudian dicari solusi penyelesaiannya. Informasi tentang memecahkan masalah matematika dapat digunakan untuk meningkatkan mutu kegiatan belajar mengajar matematika dan akhirnya diharapkan dapat meningkatkan hasil belajar matematika siswa.

\section{METODE}

Tempat penelitian dilaksanakan di SMA N 2. Penelitian dilakukan pada semester ganjil tahun ajaran 2020/2021.

Penelitian ini menggunakan pendekatan kualitatif. Jenis penelitian ini adalah penelitian kualitatif dengan metodologi penelitian deskriptif yang bertujuan untuk mengetahui deskripsi analisis kesulitan yang dilakukan siswa dalam menyelesaikan soal matematika khususnya pada materi sistem persamaan linier tiga variabel di kelas X SMAN 2 Tanjungbalai T.A 2019-2020.

Dalam penelitian ini, yang menjadi sumber data adalah siswa yang serta diberi tes. Sumber data dalam penelitian adalah subyek dari mana data dapat diperoleh, berkenaan dengan hal itu maka populasi dari penelitian ini yaitu siswa kelas X SMAN 2 Tanjungbalai T.A 2019-2020.

Adapun sampel penelitian ini adalah siswa kelas X-MIA1 SMAN 2 Tanjungbalai T.A 2019-2020, yang telah mempelajari materi sistem persamaan linier tiga variabel Siswa yang dijadikan sampel sebanyak 27 orang, yaitu 10 orang siswa laki-laki dan 17 orang siswi perempuan.

Kelas ini dijadikan subyek penelitian dikarenakan sering mengalami kesulitan dalam proses penyelesaian soal matematika. Dalam penelitian ini menggunakan empat indikator.

Teknik menganalisis penilaian siswa dilakukan dengan menghitung persentase siswa yang mengalami kesulitan setiap tahap dari soal yang diberikan, digunakan suatu rumus Sujdono (dalam Waskitoningtyas 2016:32) sebagai berikut:

$$
\text { Presentase }(\%)=\frac{F}{N} \times 100 \%
$$

Keterangan:

$\mathrm{P}=$ Presentase jawaban

$\mathrm{F}=$ Frekuensi jawaban

$\mathrm{N}=$ Banyaknya

Adapun presentase tingkat kesulitan siswa dapat dikategorikan sebagai berikut :

$0<\mathrm{P}<20$ tergolong sangat rendah $20<\mathrm{P}<40$ tergolong rendah $40<\mathrm{P}<60$ tergolong cukup $60<\mathrm{P}<80$ tergolong tinggi $80<\mathrm{P}<100$ tergolong sangat tinggi

\section{HASIL DAN PEMBAHASAN}

Analisis dilakukan kepada setiap langkah pada proses jawaban siswa disesuaikan dengan empat 


\section{MATEMATICS PAEDAGOGIC}

Vol. V No. 2, Maret 2021, hlm. 137 - 144

DOI: https://doi.org/10.36294/jmp.vxix.xxx

Available online www.jurnal.una.ac.id/indeks/jmp

indikator kesulitan siswa dengan via whatsapp.

Penggunaan whatsapp group dalam pembelajaran selama pandemi covid-19 adalah
1. Membentuk grup diaplikasi whatsapp

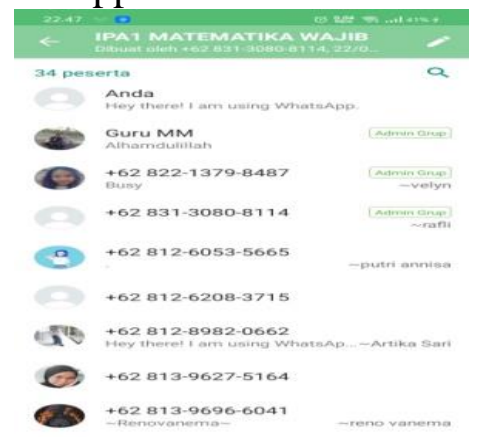

Gambar 2. Desktop grup whatsapp

2. Memberikan informasi terkait kedalam grup yang terbentuk

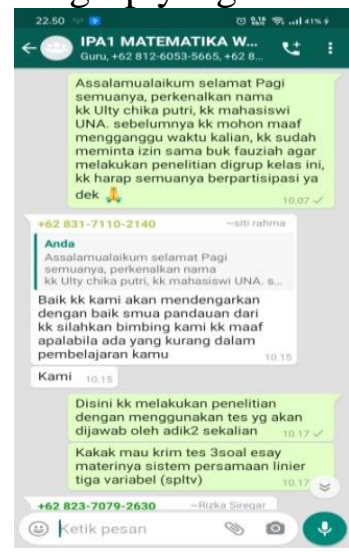

Gambar 3. Percakapan grup whatsapp

3. Berdiskusi atau informasi terkait

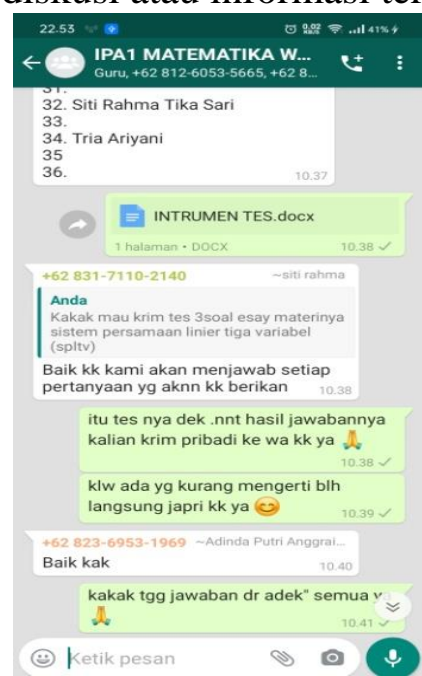

Gambar 4. Diskusi grup whatsapp

4. Mengevaluasi siswa secara individu (menginformasikan kedalam grup bahwa item soal dikerjakan secara individu )

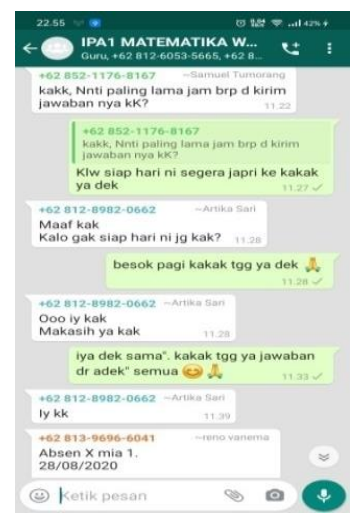

Gambar 5. Pemberian tes via grup whatsapp 


\section{MATEMATICS PAEDAGOGIC}

Vol. V No. 2, Maret 2021, hlm. 137 - 144

DOI: https://doi.org/10.36294/jmp.vxix.xxx

Available online www.jurnal.una.ac.id/indeks/jmp

5. Melakukan penilaian

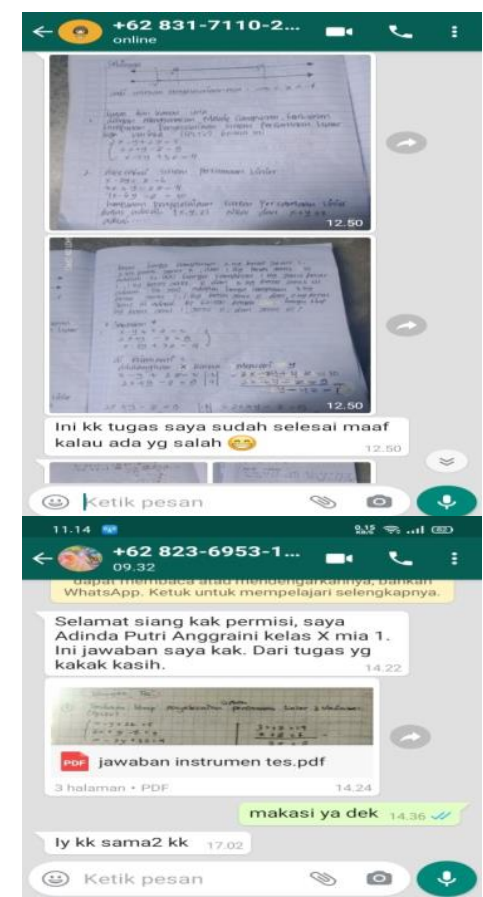

Dari 27 siswa yang memberikan jawabannya pada keempat indikator soal yang telah disajikan diperoleh hasil jawaban yang beragam dengan nilai yang berbeda-beda pada setiap indikator soal. Setelah dilakukan penilaian pada jawaban siswa, kemudian dihitung berapa presentase kesulitan tiap indikator yang dilakukan oleh siswa.

Berdasarkan analisa data yang diperoleh dari hasil penelitian, ternyata siswa kelas X SMA N 2 Tanjungbalai masih terdapat kesulitan dalam menyelesaikan soal materi sistem persamaan linier tiga variabel seperti pada tabel 1 berikut:

Gambar 6. Penilaian tes via grup whatsapp

Tabel 1. Jenis kesulitan yang dialami siswa dalam menyelesaikan soal sistem persamaan linier tiga variabel (SPLTV)

\begin{tabular}{|c|c|c|c|c|c|c|c|c|}
\hline \multirow[t]{2}{*}{ Kesulitan } & \multicolumn{3}{|c|}{ Butir soal } & \multicolumn{3}{|c|}{ Persentase kesulitan } & \multirow{2}{*}{$\begin{array}{l}\text { Total } \\
\text { Rata- } \\
\text { rata }\end{array}$} & \multirow[t]{2}{*}{ Kriteria } \\
\hline & 1 & 2 & 3 & $\mathbf{1}$ & 2 & 3 & & \\
\hline Fakta & 15 & 10 & 18 & $55,5 \%$ & $37,0 \%$ & $66,6 \%$ & $53,0 \%$ & Cukup \\
\hline Konsep & 10 & 12 & 8 & $37,0 \%$ & $44,4 \%$ & $29,6 \%$ & $37,0 \%$ & Rendah \\
\hline Operasi & 15 & 18 & 20 & $55,5 \%$ & $66,6 \%$ & $74,0 \%$ & $34,5 \%$ & Tinggi \\
\hline Prinsip & 7 & 9 & 12 & $25,9 \%$ & $33,3 \%$ & $44,4 \%$ & $65,3 \%$ & Rendah \\
\hline
\end{tabular}

Dapat dilihat dari hasil tabel tersebut diperoleh persentasi jenis kesulitan yaitu kesulitan fakta sebesar 53,0\%, kesulitan konsep sebesar 37,0\%, kesulitan operasi sebesar $65,3 \%$, dan kesulitan prinsip sebesar $34,5 \%$.

\section{SIMPULAN}

Dari pembahasan hasil penelitian yang dilakukan di kelas XMIA1 SMAN 2 Tanjungbalai dapat disimpulkan bahwa masih banyak siswa yang melakukan kesulitan belajar via whatsapp dalam proses penyelesaian soal materi sistem 
Vol. V No. 2, Maret 2021, hlm. 137 - 144

DOI: https://doi.org/10.36294/jmp.vxix.xxx

Available online www.jurnal.una.ac.id/indeks/jmp

persamaan linier tiga variabel pada masa pandemi Covid-19 dapat kita lihat persentase rata-rata kesulitan yang dialami siswa yaitu sebagai berikut:

1. Rata-rata kesulitan fakta siswa dalam menyelesaikan soal sistem persamaan linier tiga variabel (SPLTV) adalah 53,0\% tergolong cukup.

2. Rata-rata kesulitan konsep siswa dalam menyelesaikan soal sistem persamaan linier tiga variabel

\section{DAFTAR RUJUKAN}

Anim, A. (2020). Persepsi Mahasiswa Pendidikan Matematika Tentang

Pembelajaran Daring Selama Masa Learn from Home (LFH) Pandemic Covid-19. JURNAL MATHEMATIC

PAEDAGOGIC, 5(1), 72-80.

Anim, A., \& Nisa, K. (2020, October). PERSEPSI DOSEN

FKIP TENTANG

PERKULIAHAN DARING

SEBAGAI SARANA
PEMBELAJARAN DI MASA COVID-19. In Seminar Nasional Multi Disiplin Ilmu Universitas Asahan.

Kusuma, J.W., (2020), Perbandingan Hasil Belajar Matematika dengan Penggunaan Platform Whatsapp Group dan Webinar Zoom dalam Pembelajaran Jarak Jauh Pada Masa Pandemi Covid-19, Jurnal Ilmiah Pendidikan Matematika 1:97106.
(SPLTV) adalah 37,0\% tergolong rendah.

3. Rata-rata kesulitan operasi siswa dalam menyelesaikan soal sistem persamaan linier tiga variabel (SPLTV) adalah 65,3\% tergolong tinggi.

4. Rata-rata kesulitan prinsip siswa dalam menyelesaikan soal sistem persamaan linier tiga variabel (SPLTV) adalah 34,5\% tergolong rendah.
Mapilindo, M., \& Anim, A. (2020, October). PERSEPSI MAHASISWA FKIP TENTANG

PEMBELAJARAN DARING SELAMA PANDEMI COVID19. In Seminar Nasional Multi Disiplin Ilmu Universitas Asahan.

Pratiwi, E.W., (2020), Dampak Covid-19 Terhadap Kegiatan Pembelajaran Online disebuah Perguruan Tinggi Kristen di Indonesia, Perspektif Ilmu Pendidikan 1:1-8.

Waskitoningtyas, R.S., (2016), Analisis Kesulitan Belajar Matematika Siswa Kelas V Sekolah Dasar Kota Balik Papan Pada Materi Satuan Waktu Tahun Ajaran 2015/2016, Jurnal Ilmiah Pendidikan Matematika 1:2432. 